Vol. 1, No. 3, 2019

\title{
IMPLEMENTASI FUZZY LOGIC PADA PERILAKU NPC (NON PLAYER CHARACTER) DALAM TINGKAT KEPUASAN PELAYANAN PADA GAME MLIJO 2D BERBASIS MOBILE
}

\author{
Sely Prastikasari' ${ }^{1}$, Amak Yunus ${ }^{2}$, Danang Aditya Nugraha ${ }^{3}$ \\ Teknik Informatika, Universitas Kanjuruhan Malang ${ }^{1,2,3}$ \\ sellyrik@gmail.com¹, amakyunus@unikama.ac.id ${ }^{2}$, danang.adty@unikama.ac.id ${ }^{3}$
}

\begin{abstract}
Abstrak. NPC (Non Player Character) merupakan karakter otonom yang sudah ditentukan rule/aturan pergerakannya oleh komputer pada sebuah game. Dalam game bertema pelayanan, NPC berperan penting pada kualitas game dan daya tarik game tersebut. Dalam Game bernama " Mlijo", NPC berperan sebagai konsumen dimana dibutuhkan beberapa perilaku NPC dan penerapan artificial intelligence (AI) dalam game tersebut. Penerapan fuzzy mamdani pada game Mlijo ini terdapat pada perilaku dalam kepuasan pelayanan NPC berupa mimik wajah. Hasil yang diperoleh berupa nilai dari beberapa mimik wajah NPC yaitu puas, biasa dan kecewa yang berhubungan dengan waktu NPC, kualitas barang dan harga yang ditawarkan dengan menggunakan bahasa \#C pada game engine unity $2 \mathrm{D}$.
\end{abstract}

Kata Kunci: NPC (Non Player Character), artificial intelligence (AI), fuzzy mamdani

\section{PENDAHULUAN}

Game yang bertema masakan sangat banyak kita jumpai dan mainkan. Di Indonesia sendiri banyak game yang bertema masakan dan banyak yang mengenalkan masakan-masakan lokal di Indonesia. Akan tetapi, kebanyakan game masakan menyediakan masakan jadi, sehingga kita juga lebih sulit mengenal bahan-bahannya. Selain itu dalam segi tingkat pelayanan terhadap konsumen berupa karakter NPC (Non Player Character) yang digunakan pada game memasak itu sendiri belum begitu detail. kebanyakan dari mereka hanya menggunakan pelayanan pelanggan dari segi kecepatan waktu yaitu terletak pada konsumen (NPC) yang berpengaruh pada mimik konsumen (NPC) saja. Untuk itu perlu pengembangan dari game tersebut dan pengimplementasiannya ke dalam sebuah metode berupa kecerdasan buatan.

Penelitian sebelumnya yang dilakukan oleh (Nur Hidayah, Muliadi dan Ichsan Ridwan, 2016) yaitu tentang Algoritma Boids dan Logika Fuzzy pada Pergerakan dan Perilaku Non Player Characters Permainan Borneo Mission. Penelitian ini membangun game first person shooter $3 \mathrm{D}$ dimana pergerakan dan perilaku non player character menerapkan algoritma boids dan logika fuzzy mamdani. Pada pergerakan drone menggunakan algoritma boids dimana hasil dengan menerapkan algoritma boids drone dapat terbang secara berkelompok dengan mempertimbangkan separation, cohesion dan aligment dengan drone lain. Sedangkan pada perilaku drone menggunakan fuzzy mamdani dimana hasil dengan menerapkan fuzzy mamdani drone dapat memutuskan menyerang, menghindar atau menyelamatkan transceiver.

Penggunaan fuzzy logic mamdani lebih cocok dalam penerapan game ini pada output yang menghasilkan kepuasan NPC yang menghasilkan mimik wajah NPC dimana dibutuhkan perhitungan nilai dalam penentuan hasil yang ditunjukan berupa mimik wajah $N P C$ dari perhitungan parameter yang ada dengan detail dan terperinci.

Dari pernyataan diatas, penelitian ini berinisiatif mengembangkan game dengan judul "Implementasi Fuzzy Logic pada Perilaku NPC (Non Player Character) dalam Tingkat Kepuasan Pelayanan pada Game "Mlijo" 2D Berbasis Mobile".

Penelitian ini bertujuan untuk menerapkan dan menguji Fuzzy Logic pada perilaku NPC (Non Player Character) dalam tingkat kepuasan pelayanan berdasarkan waktu NPC, kualitas 
barang dan harga yang ditawarkan pada game mlijo 2D berbasis mobile. Sehingga terdapat batasan-batasan dalam pembuatannya antara lain:

1. Game ini dibuat dengan Game Engine Unity 2D berbasis mobile.

2. Fuzzy Logic yang digunakan adalah Fuzzy Logic Mamdani, dimana pengimplementasian nya pada perilaku NPC (Non Player Character) dalam tingkat kepuasan pelayanan berupa mimik wajah/ekspresi wajah.

3. Pemain game mlijo versi beta ini adalah single player.

4. Target pengguna game ini yaitu usia antara 13 tahun ke atas.

5. Desain Environment, karakter, level map dan main menu disajikan dalam bentuk dua dimensi.

6. Game versi beta ini hanya dibuat 1 stage level yang berisi 3 level.

7. Game ini dapat dimainkan secara offline.

8. Penelitian pada implementasi metode fuzzy mamdani didalam game Mlijo ini hanya dilakukan pada satu NPC dalam 1 level.

\section{METODE PENELITIAN}

\section{Penentuan Konsep}

Pada game ini bernama "Mlijo". Game mlijo merupakan game berjenis arcade yang dimainkan oleh satu player (single player) dimana menceritakan tentang seorang pedagang keliling yang menjual aneka bahan makanan serta kue tradisional. Nama dari Mlijo sendiri merupakan sebutan unik dari daerah Malang, Jawa Timur pada pedagang keliling itu sendiri. Pada game mlijo terdiri dari beberapa karakter NPC sebagai pembeli dan assets lainnya seperti environment, tools dan sound effect yang ada di dalam game. Sedangkan pada kecerdasan buatan menggunakan metode fuzzy mamdani khususnya pada kepuasan pelayanan NPC berupa mimik wajah.

\section{Perancangan sistem}

Pada game Mlijo terdapat beberapa perancangan dalam pembuatan game tersebut antara lain:

a. Perancangan storyboard

Perancangan storyboard pada game mlijo menggunakan animasi trailer/ pembuka sebelum berada pada gameplay. Pada game Mlijo menggunakan keterangan latar berupa durasi 180 detik, tempat didaerah malang dan terdapat 11 scene gambar.

b. Perancangan assets game

Assets gambar pada game Mlijo yaitu 2 dimensi dimana pengerjaannya menggunakan aplikasi CorelDraw X5 dengan skala pixel yang ukurannya disetarakan dengan ukuran mobile dan gambar berformat png.

c. Perancangan gameplay

Adapun perancangan gameplay dari game Mlijo antara lain:

1. Pada awal permainan terdapat tampilan splash screen logo pembuat dengan durasi waktu beberapa detik.

2. Selanjutnya, terdapat loading bar untuk loading ke tampilan setelahnya.

3. Sebelum berada pada permainan, terdapat tampilan menu utama yang berisi main, help, credit dan exit. Dimana menu main untuk menuju permainan, menu help untuk meminta bantuan jika terdapat kesulitan bermain, menu credit untuk mengetahui developernya informasi game dan menu exit untuk keluar dari permainan.

4. Pada game Mlijo terdapat satu stage yang terdiri dari tiga level yang harus dilalui. 
5. Pada level 1, Pembeli (NPC) hanya terdapat tiga karakter NPC. Target poin pada level ini masih rendah. Permintaan yang diinginkan pembeli (NPC) beragam dan bersifat random, akan tetapi pada level ini belum banyak komposisi yang dinginkan pembeli (NPC).

6. Pada game ini, terdapat kondisi menang jika player dapat mencapai poin yang telah ditentukan atau lebih. Maka player bisa bermain ke level selanjutnya.

7. Pada game ini, terdapat kondisi kalah jika player tidak dapat mencapai poin yang telah ditentukan atau lebih. Maka player tidak bisa bermain ke level selanjutnya.

d. Flowchart Gameplay

Alur proses gameplay Mlijo berawal dari start lalu memasuki level 1 pada game jika pemain berhasil melewati level 1 maka akan melanjutkan ke level selanjutnya, tetapi jika pemain tidak berhasil melawati level 1 maka akan muncul menu game over yang terdapat beberapa pilihan yaitu reload atau kembali ke main menu jika pemain memilih reload maka pemain akan mengulang game level yang di mainkan jika kembali ke main menu maka pemain akan kembali ke menu utama sesuai dengan gambar dibawah.

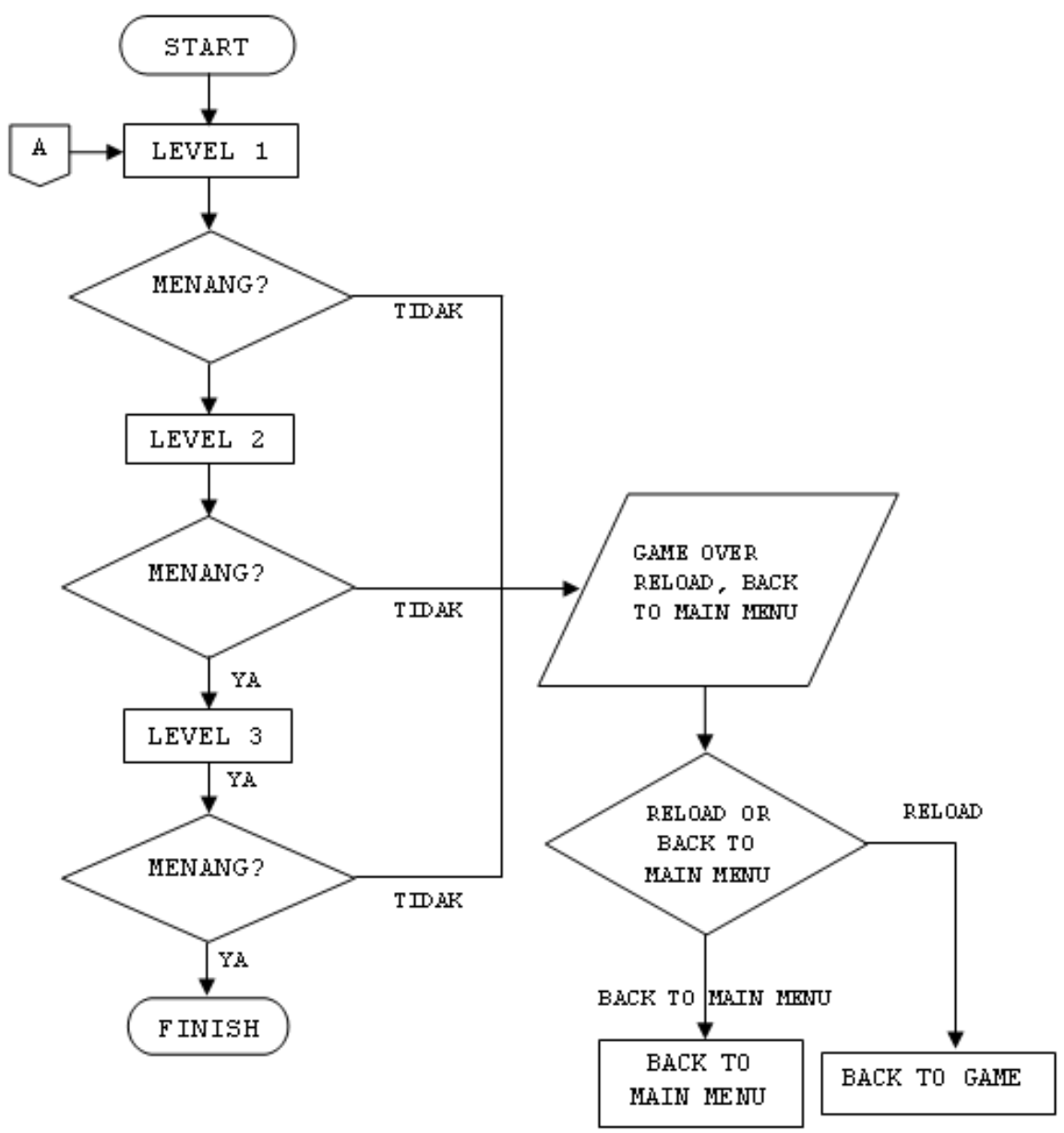

Gambar 1. Flowchart Gameplay Mlijo

\section{Algoritma Game}

a. Skenario Perubahan Pelaku pada NPC

NPC pada game Mlijo menjadi objek penelitian ini. NPC mempunyai tingkat kepuasan dan mimik wajah yang beragam serta variabel yang mempengaruhi perubahan dan poin pada perilaku seperti tabel dibawah ini. 
Tabel 1. Variabel Perubahan NPC

\begin{tabular}{cll}
\hline \multicolumn{1}{c}{ NPC } & \multicolumn{1}{c}{ Input } & \multicolumn{1}{c}{ Output } \\
\hline Konsumen/pembeli & Waktu $N P C$, kualitas barang & Tingkat kepuasan \\
& $\begin{array}{l}\text { dan Harga yang Ditawarkan } \\
\text { (Poin) }\end{array}$ & $\begin{array}{l}\text { pelayanan NPC berupa } \\
\text { mimik wajah }\end{array}$ \\
\hline
\end{tabular}

b. Algoritma Fuzzy Mamdani

- Flowchart fuzzy mamdani

Dalam game mlijo algoritma fuzzy mamdani berperan penting dalam penentuan tingkat kepuasan pelayanan berdasarkan mimik wajah NPC terhadap waktu NPC, kualitas barang dan harga yang ditawarkan.

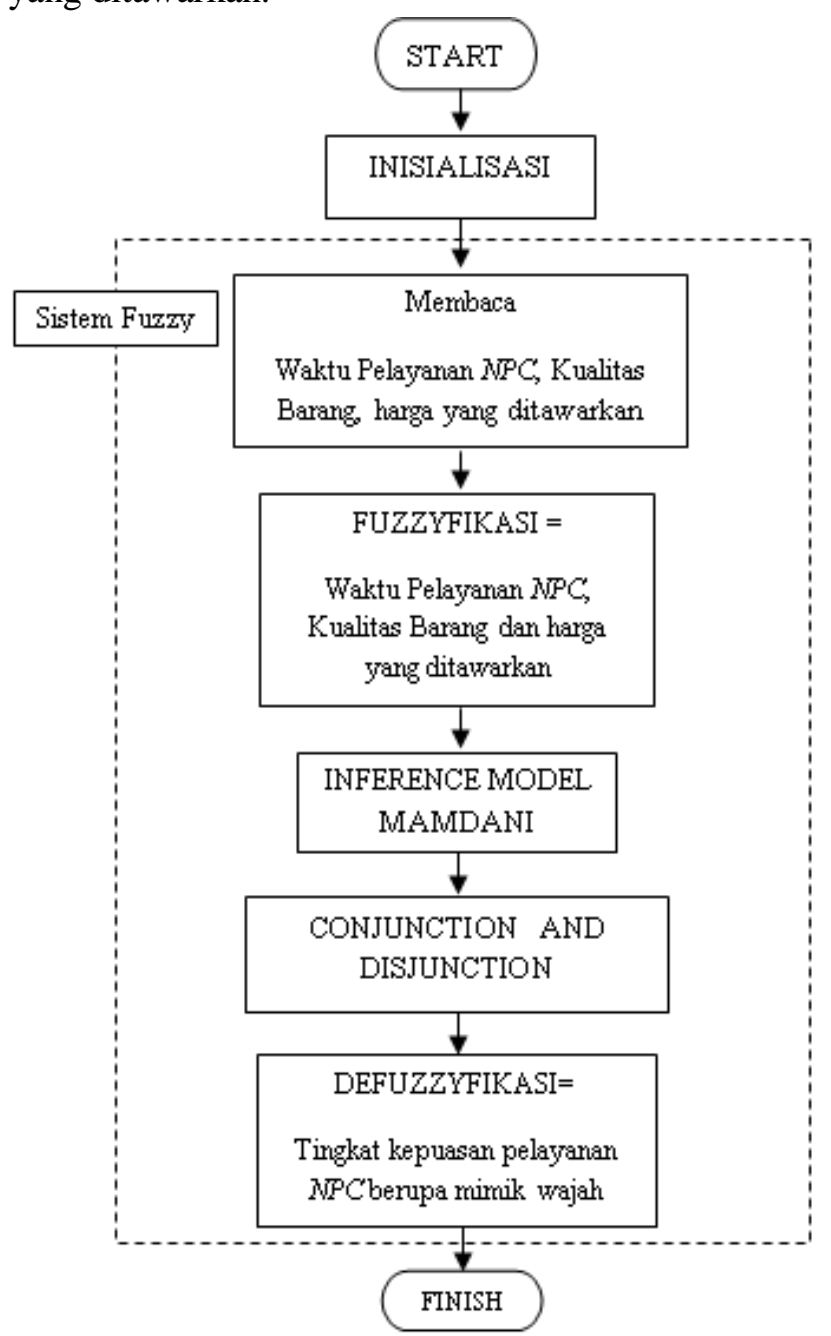

Gambar 2. Flowchart Fuzzy Mamdani

- Deklarasi Metode Fuzzy Mamdani

waktuNPC,kualitasbarang,hargayangditawarkan,TimeNPC_Senang,TimeNPC_

Biasa,TimeNPC_Kecewa, KB_Bagus, KB_Biasa, KB_Jelek, HrgYgD_Mrh, HrgYgD_Ckp, HrgYgD_Mhl = Float

- Deskripsi Metode Fuzzy Mamdani

1. Inisialisasi waktu NPC, kualitas barang dan harga yang ditawarkan, TimeNPC_Senang, TimeNPC_Biasa,TimeNPC_Kecewa,KB_Bagus, KB_Biasa, KB_Jelek, HrgYgD_Mrh, HrgYgD_Ckp, HrgYgD_Mhl

2. Selesai pelayanan 
3. Mengambil nilai waktu NPC, kualitas barang dan harga yang ditawarkan

4. Proses fuzzyfikasi waktu NPC, Kualitas barang dan harga yang ditawarkan.

5. Proses inferensi model mamdani

6. Proses conjuction menggunakan metode MIN

7. Proses Disjunction menggunakan metode MAX

8. Defuzzyfikasi menggunakan metode centroid.

9. Hasil defuzzyfikasi mengeluarkan nilai yang nantinya akan menjadi output berupa perubahan mimik wajah NPC

Selesai

\section{HASIL DAN PEMBAHASAN}

\section{Implementasi Metode Fuzzy Mamdani}

Menurut (Suyanto, 2014) penjelasan perhitungan fuzzy mamdani yang diterapkan pada mimik wajah dalam game Mlijo adalah sebagai berikut:

a. Fuzzifikasi

Pada algoritma fuzzy sistem pada kepuasan pelayanan di dalam game mlijo menggunakan 3 inputan yaitu waktu pelayanan NPC, kualitas barang dan harga yang ditawarkan. Sedangkan variabel output adalah kepuasan pelayanan NPC berupa mimik wajah. Pada proses fuzzyfikasi , output yang berupa inputan waktu pelayanan NPC digunakan variabel linguistik yaitu senang (0 -8 second), biasa (6 - 15 second), kecewa (14 - 20 second). Untuk kualitas barang digunakan variabel linguistik yaitu bagus (0-70 second), biasa (50-130 second), jelek (110-180 second). Untuk harga yang ditawarkan digunakan variabel linguistik yaitu murah (0-350), cukup (250750), mahal (650-1000).

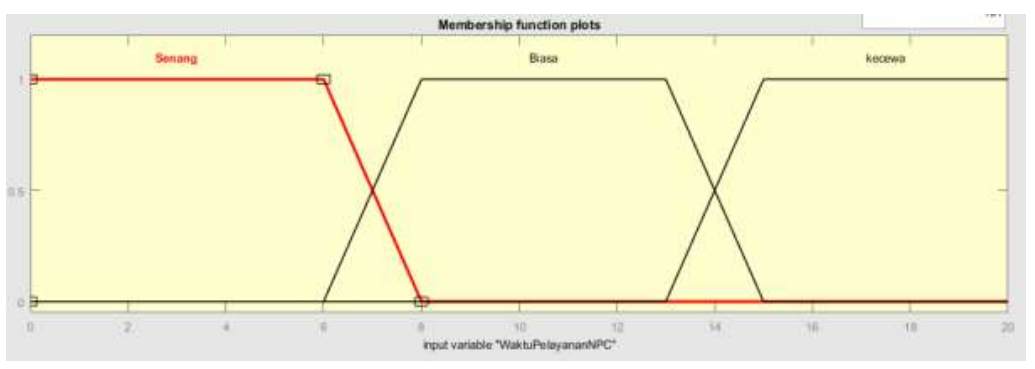

Gambar 3. Fungsi Keanggotaan Waktu NPC

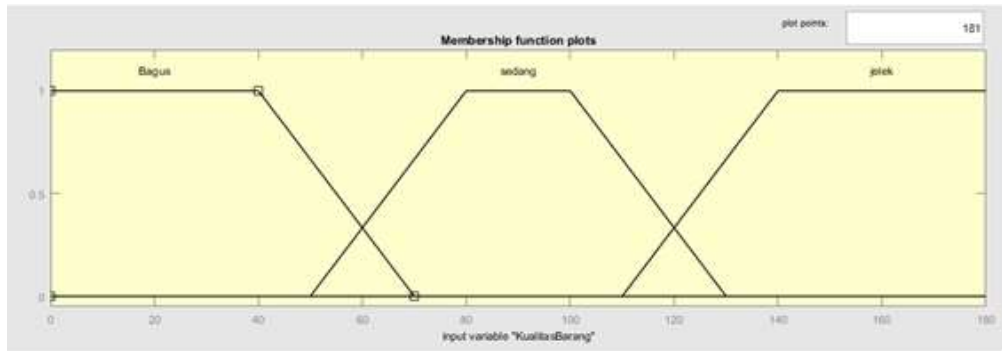

Gambar 4. Fungsi keanggotaan Kualitas Barang

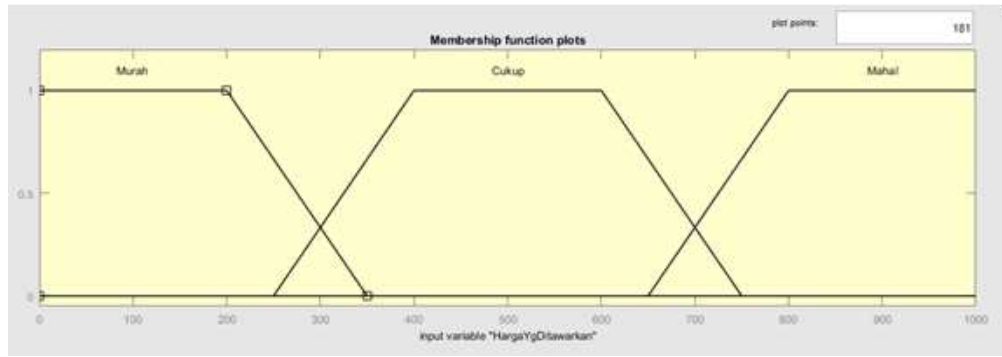

Gambar 5. Fungsi keanggotaan Harga yang ditawarkan 


\section{b. Rancangan Membership}

Pada membership function ini berperan penting pada sistem dalam game karena elemen keanggotaan dari membership function ini berfungsi sebagai input dan output untuk nilai yang dihasilkan oleh sistem dalam game Mlijo.

Adapun studi kasus fuzzy mamdani adalah sebagai berikut: Rupiah

Pada waktu NPC 7 detik dengan kualitas barang 62 detik dan harga yang ditawarkan 320

a. Variabel linguistik waktu NPC terdapat 3 yang digunakan yaitu senang, biasa kecewa. Pada nilai 7 detik termasuk kategori senang dan biasa.

b. Variabel linguistik kualitas barang terdapat 3 yang digunakan yaitu bagus, biasa, jelek. Pada nilai 62 detik termasuk kategori bagus dan biasa.

c. Variabel linguistik harga yang ditawarkan terdapat 3 yang digunakan yaitu murah, cukup, mahal. Pada nilai 320 rupiah termasuk kategori murah dan cukup.

- Penentuan rule (aturan)

If (WaktuPelayananNPC is Senang) and (KualitasBarang is Bagus) and (HargaYgDitawarkan is murah) then (KepuasanPelayananNPC is Puas)

If (WaktuPelayananNPC is Senang) and (KualitasBarang is Bagus) and (HargaYgDitawarkan is Cukup) then (KepuasanPelayananNPC is Biasa)

If (WaktuPelayananNPC is Senang) and (KualitasBarang is Biasa) and (HargaYgDitawarkan is murah) then (KepuasanPelayananNPC is Puas)

If (WaktuPelayananNPC is Senang) and (KualitasBarang is Biasa) and (HargaYgDitawarkan is Cukup) then (KepuasanPelayananNPC is Biasa)

If (WaktuPelayananNPC is Senang) and (KualitasBarang is Jelek) AND (HargaYgDitawarkan is Cukup) then (KepuasanPelayananNPC is Biasa)

If (WaktuPelayananNPC is Biasa) AND (KualitasBarang is Bagus) AND (HargaYgDitawarkan is murah) then (KepuasanPelayananNPC is Puas)

If (WaktuPelayananNPC is Biasa) AND (KualitasBarang is Bagus) AND (HargaYgDitawarkan is Cukup) then (KepuasanPelayananNPC is Biasa)

If (WaktuPelayananNPC is Biasa) AND (KualitasBarang is Bagus) AND (HargaYgDitawarkan is Mahal) then (KepuasanPelayananNPC is Kecewa)

If (WaktuPelayananNPC is Biasa) AND (KualitasBarang is Biasa) AND (HargaYgDitawarkan is Cukup) then (KepuasanPelayananNPC is Biasa)

If (WaktuPelayananNPC is Biasa) AND (KualitasBarang is Biasa) AND (HargaYgDitawarkan is Mahal) then (KepuasanPelayananNPC is Kecewa)

If (WaktuPelayananNPC is Biasa) AND (KualitasBarang is Jelek) AND (HargaYgDitawarkan is Cukup) then (KepuasanPelayananNPC is Biasa)

If (WaktuPelayananNPC is Biasa) AND (KualitasBarang is Jelek) AND (HargaYgDitawarkan is Mahal) then (KepuasanPelayananNPC is Kecewa)

If (WaktuPelayananNPC is kecewa) AND (KualitasBarang is Bagus) AND (HargaYgDitawarkan is Mahal) then (KepuasanPelayananNPC is Kecewa)

If (WaktuPelayananNPC is kecewa) AND (KualitasBarang is Biasa) AND (HargaYgDitawarkan is Mahal) then (KepuasanPelayananNPC is Kecewa)

If (WaktuPelayananNPC is kecewa) AND (KualitasBarang is Jelek) AND (HargaYgDitawarkan is Mahal) then (KepuasanPelayananNPC is Kecewa) 
- Menentukan Derajat Keanggotaan

Fuzzy mamdani pada game Mlijo menggunakan bentuk fungsi keanggotaan trapezium dalam 3 inputan yaitu waktu NPC, kualitas barang dan harga yang ditawarkan dengan rumus:

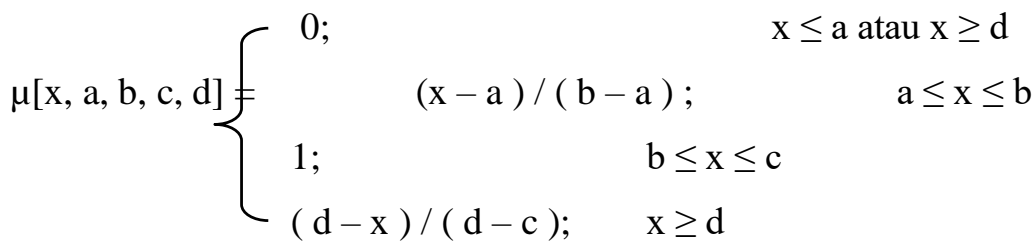

Keterangan:

$\mathrm{A}=$ nilai dominan terkecil yang mempunyai derajat keanggotaan nol.

$\mathrm{B}=$ nilai domain yang mempunyai derajat keanggotaan satu.

$\mathrm{C}=$ nilai domain terbesar yang mempunyai derajat keanggotaan satu.

$\mathrm{D}=$ nilai domain terbesar yang mempunyai derajat keanggotaan nol.

Sehingga dihasilkan 6 inputan yaitu:

Tabel 2. Hasil nilai Fungsi keanggotaan

\begin{tabular}{cccclc}
\hline \multicolumn{2}{c}{ Waktu NPC } & \multicolumn{2}{c}{ Kualitas Barang } & \multicolumn{2}{c}{ Harga yang ditawarkan } \\
\hline Senang & 0,5 & Bagus & 0,4 & Murah & 0,3 \\
\hline Biasa & 0,5 & Biasa & 0,6 & Cukup & 0,7 \\
\hline
\end{tabular}

Pada metode fuzzy mamdani dalam game Mlijo menggunakan operasi fuzzy fungsi AND yaitu mengambil nilai MAX dari derajat keanggotaan setiap input fuzzy.

- Implikasi Dan Komposisi aturan

Pencarian inferensi nilai pada model mamdani diikuti dengan pencarian implikasi dan komposisi aturan. Pada proses Implikasi atau yang biasa disebut conjunction yaitu nilai dari fungsi keanggotaan dan fungsi rule menggunakan perhitungan nilai min (minimum). Sedangkan pada proses komposisi aturan atau yang biasa disebut disjunction menggunakan metode max. Sehingga nilai yang diperoleh pada output berupa kepuasan pelayanan adalah 0,3 dalam kategori puas dan 0,5 dalam kategori biasa dengan grafik dibawah ini.

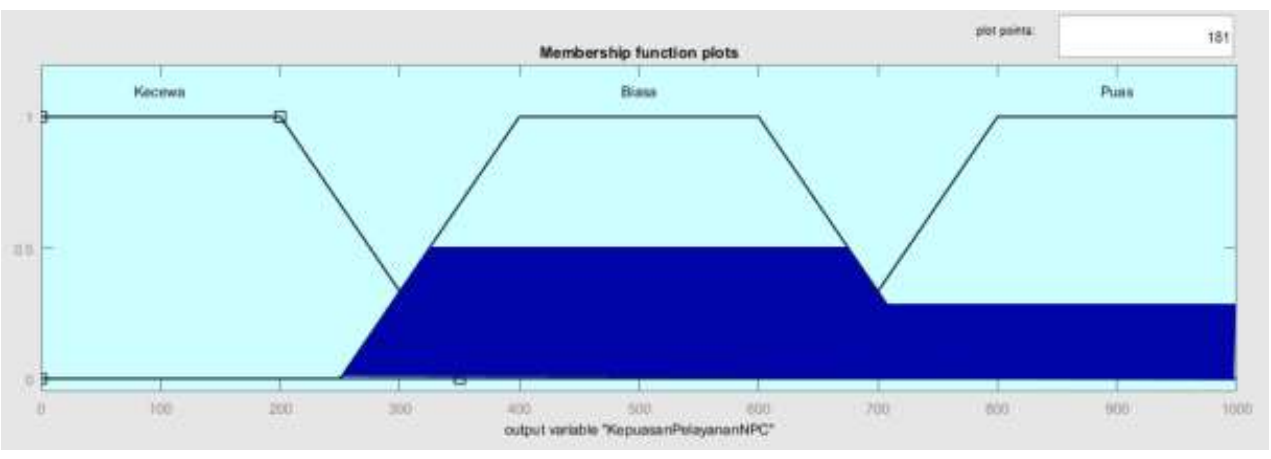

Gambar 6. Proses Compotition pada model mamdani dari fuzzy set, puas dan biasa. Menghasilkan satu fuzzy set tunggal yang di tunjukan oleh area berwarna biru tua.

- Inference Model Mamdani

Pada Inference model mamdani menggunakan fungsi keanggotaan singleton yaitu fungsi keanggotaan yang memiliki derajat keanggotaan 1 pada suatu nilai crips tunggal dan 0 pada semua nilai crisp yang lain. 
- Defuzzyfikasi

Pada metode fuzzy mamdani defuzzyfikasi menggunakan model centroid dengan rumus sebagai berikut:

$$
\mathrm{Z}_{0}=\frac{\int_{a}^{b} Z \cdot \mu(z) d z}{\int_{a}^{b} \mu(z) d z}
$$

Keterangan:

$\mathrm{Z} \quad=$ nilai domain $\mathrm{ke}-\mathrm{i}$

$\mu(z)=$ derajat keanggotaan titik tersebut.

$\mathrm{Z}_{0}=$ nilai hasil penegasan (defuzzifikasi).

\section{Pengujian Sistem}

\section{- Spesifikasi Pengujian Perangkat}

Berikut ini adalah spesifikasi perangkat keras yang digunakan peneliti dalam proses pembuatan dan uji coba game Mlijo.

$\begin{array}{ll}\text { Sistem Operasi } & : \text { Android Versi 6.0 XOS X601 LTE } \\ \text { CPU } & : \text { MediaTek Helio X10 MT6795M Octa-Core } \\ \text { RAM } & : 3 \mathrm{~GB} \\ \text { Internal Memory } & : 16 \mathrm{~GB}\end{array}$

\section{- Pengujian Metode Fuzzy Mamdani}

Pengujian metode fuzzy mamdani dalam game ini menggunakan metode black box. Pengujian di dalam game ini mencakup perubahan mimik wajah menggunakan metode fuzzy mamdani yang nanti akan mengahasilkan tiga mimik wajah yang berbeda sesuai perubahan hasil dari variable yang di dapat saat selesai melayani customer. Pengujian dilakukan setiap kali customer selesai mendapatkan pesanan, dimana tabel yang dihasilkan sebagai berikut:

Tabel 3. Pengujian Metode Fuzzy Mamdani didalam Game Mlijo

\begin{tabular}{|c|c|c|c|c|}
\hline Pengujian & $\begin{array}{l}\text { Tes } \\
\text { ID }\end{array}$ & $\begin{array}{l}\text { Hasil yang } \\
\text { diharapkan }\end{array}$ & $\begin{array}{c}\text { Hasil } \\
\text { Pengamatan }\end{array}$ & Kesimpulan \\
\hline \multirow{2}{*}{$\begin{array}{c}\text { Metode } \\
\text { Fuzzy } \\
\text { Mamdani } \\
\text { didalam } \\
\text { Game Mlijo }\end{array}$} & M-14 & $\begin{array}{l}\text { Terdapat hasil } \\
\text { perubahan } \\
\text { ekspresi / mimic } \\
\text { wajah NPC } \\
\text { selama waktu } \\
\text { yang ditentukan }\end{array}$ & Berhasil & $\begin{array}{c}\text { Proses hasil } \\
\text { perubahan } \\
\text { ekspresi / mimik } \\
\text { wajah NPC } \\
\text { selama waktu } \\
\text { yang ditentukan } \\
\text { dapat berjalan } \\
\text { dengan baik }\end{array}$ \\
\hline & M-15 & $\begin{array}{c}\text { Terdapat hasil } \\
\text { perubahan } \\
\text { kualitas barang } \\
\text { selama waktu } \\
\text { yang ditentukan }\end{array}$ & Berhasil & $\begin{array}{c}\text { Proses hasil } \\
\text { perubahan } \\
\text { kualitas barang } \\
\text { selama waktu } \\
\text { yang ditentukan } \\
\text { dapat berjalan } \\
\text { dengan baik }\end{array}$ \\
\hline
\end{tabular}




\begin{tabular}{|c|c|c|c|}
\hline M-16 & $\begin{array}{l}\text { Terdapat hasil } \\
\text { total uang yang } \\
\text { diperoleh }\end{array}$ & Berhasil & $\begin{array}{c}\text { Proses hasil } \\
\text { total uang yang } \\
\text { diperoleh pada } \\
\text { inputan harga } \\
\text { yang ditawarkan } \\
\text { dapat berjalan } \\
\text { dengan baik }\end{array}$ \\
\hline
\end{tabular}

Sedangkan pada implementasi didalam gamenya menggunakan bahasa \#C dengan game engine unity adalah sebagai berikut:

- Proses Input

Pada game Mlijo terdapat 3 input yang terbaca dalam sistem yaitu:

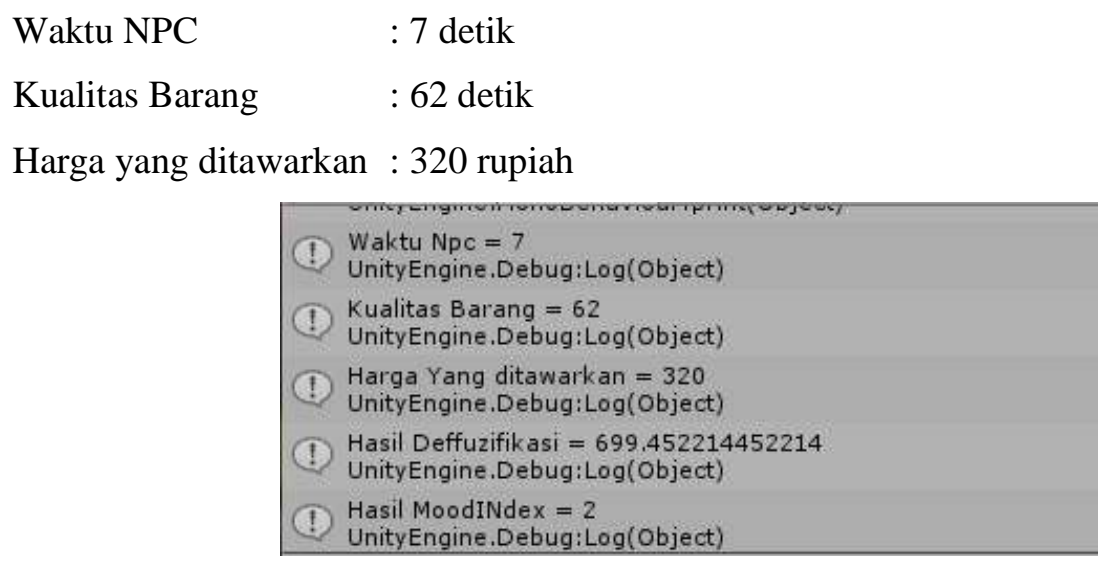

\section{Gambar 7. Hasil Pengujian Sistem}

Pada pemberian nilai inputan, maka perhitungan sebelumnya diperoleh nilai dari hasil output sebesar 699.452214452214 atau 699.

Pada gambar diatas dijelaskan bahwa hasil dari input Waktu NPC : 7 detik, Kualitas Barang : 62 detik dan Harga yang ditawarkan : 320 rupiah memperoleh hasil nilai output 699 yang nantinya akan dihubungkan pada mimik wajah dengan kategori puas sesuai gambar dibawah.

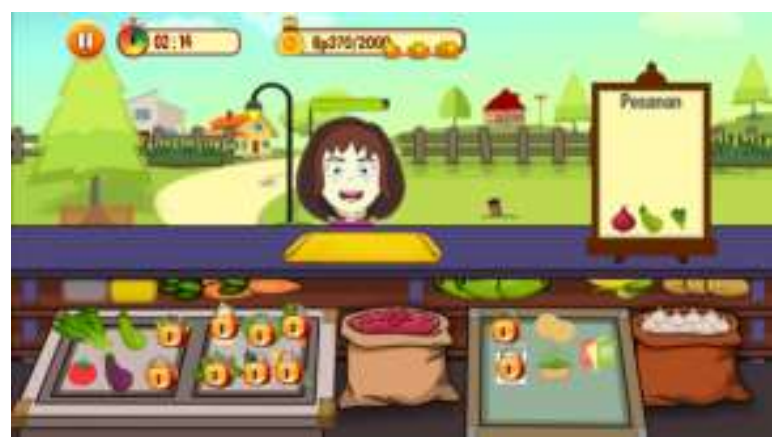

Gambar 8. Hasil output kepuasan pelayanan didalam game Mlijo

\section{PENUTUP}

\section{Kesimpulan}

Berdasarkan penerapan metode fuzzy mamdani didalam game Mlijo dapat diimplementasikan pada 3 parameter yaitu waktu pelayanan NPC, kualitas barang dan harga yang ditawarkan untuk menghasilkan satu output yaitu kepuasan pelayanan berupa mimik wajah NPC 
baik berupa perhitungan manual maupun pada source code dalam game menggunakan fuzzy model mamdani. Pengujian pada game Mlijo menggunakan blackbox baik pada pengujian game maupun metode fuzzy mamdani yang ada dalam game. Dari hasil pengujian blackbox dari game Mlijo berdasarkan tampilan splash screen, menu utama, level maps, scene main, pop up misi, pop up pause dan pop up end game dapat berjalan sesuai yang diinginkan. Sedangkan dari hasil pengujian blackbox dari metode fuzzy mamdani berdasarkan 3 inputan yaitu waktu pelayanan NPC, kualitas barang dan harga yang ditawarkan untuk menghasilkan satu output yaitu kepuasan pelayanan berupa mimik wajah NPC dapat berjalan sesuai dengan harapan serta pembuktian perhitungan manual dengan menggunakan perhitungan model mamdani untuk waktu NPC 7 detik, kualitas barang 62 detik dan harga yang ditawarkan sebesar 320 rupiah, maka perhitungan yang dihasilkan adalah poin 699 dimana poin tersebut masuk dalam kategori hasil mimik wajah NPC puas.

\section{Saran}

Berdasarkan hasil perancangan, implementasi dan pengujian pada game Mlijo ini masih memiliki kekurangan. Sehingga perlu dikembangkan kedepannya menjadi lebih baik dan sempurna. Untuk itu, saran yang harus diperhatikan dalam pembuatan game Mlijo ini adalah sebagai berikut:

1. Penelitian lanjutan yang dibutuhkan pengembangan tentang perilaku NPC terutama pada kepuasan pelayanan dengan NPC berupa mimik wajah dengan menggunakan metode fuzzy mamdani baik penambahan variabel input atau output.

2. Pembuatan tampilan game, animasi, serta sound effect yang membutuhkan pengembangan lanjutan agar tampilan game lebih bagus serta lebih variasi.

3. Pengembangan dari tingkat kompleks dari game Mlijo. Banyak fitur-fitur tambahan yang dibutukan pengembangan mulai dari NPC, kualitas barang, komposisi barang, penyajian pesanan NPC, tampilan barang yang dipesan NPC serta harga yang ditawarkan.

\section{DAFTAR PUSTAKA}

Hidayah, Nur, Mulyadi, Ichsan Ridwan. 2016. "Algoritma Boids dan Logika Fuzzy pada Pergerakan dan Perilaku Non Player Characters Permainan Borneo Mission”. Kalimantan Selatan: Kumpulan Jurnal Ilmu Komputer, ISSN 2406- 7857

Suyanto. 2014. Artificial Intelligence Searching, Reasoning, Planning dan Learning. Bandung: Informatika Bandung, ISBN 978-602-1514-44-3 